\title{
Impact of preoperative atrial fibrillation on mortality and cardiovascular outcomes in patients undergoing double valve surgery
}

\author{
M Urban*, J Pirk, O Szarszoi, P Ivak, I Netuka \\ From 23rd World Congress of the World Society of Cardio-Thoracic Surgeons \\ Split, Croatia. 12-15 September 2013
}

\section{Background}

The prognostic significance of atrial fibrillation (AF) on postoperative outcomes and survival of patients following concomitant aortic and mitral valve surgery remains unclear. The aim of his study was to assess the impact of the presence of the preoperative AF on the outcome.

\section{Methods}

This was a retrospective study of 341 patients who underwent double valve replacement with either tissue $(\mathrm{n}=164)$ or mechanical $(\mathrm{n}=177)$ prostheses. The patients were divided into two groups according to preoperative rhythm status. Demographic, clinical and echocardiographic data were extracted from the hospital database and patient notes. Follow-up data were gathered through outpatient visits or mailed structured questionnaire. Data were analyzed for major adverse valve related complications and survival.

\section{Results}

Follow-up was 93\% complete and totaled 1398 patientyears. Although patients with preoperative AF were significantly older, presented with higher logistic EuroScore and larger left atria on echocardiographic examination, five year survival was comparable $(83 \pm 4 \%$ SR vs. $75 \pm 4 \% \mathrm{AF}, \mathrm{p}=0.194)$. Patients with preoperative AF who underwent replacement with tissue valves with MAZE had $68 \pm 10 \%$ five year survival in comparison to $38 \pm 11 \%$ without MAZE procedure $(\mathrm{p}=0.032)$. There was no difference in survival in patients who underwent replacement with mechanical prostheses with or without MAZE ( $85 \pm 7 \%$ vs. $87 \pm 3 \%, p=0.216)$. Freedom from

\footnotetext{
* Correspondence: maub@ikem.cz

Department of Cardiac Surgery, Institute for Clinical and Experimental Surgery, Prague, Czech Republic
}

(c) 2013 Urban et al; licensee BioMed Central Ltd. This is an Open Access article distributed under the terms of the Creative Commons Attribution License (http://creativecommons.org/licenses/by/2.0), which permits unrestricted use, distribution, and reproduction in any medium, provided the original work is properly cited. major adverse valve related complications at five years was $81 \pm 4 \%$ in SR and $73 \pm 5 \%$ in AF group ( $p=0.189$ ). Multivariate analysis identified older age, higher EuroScore, preoperative renal insufficiency and concomitant CABG as significant adverse predictors for overall survival.

\section{Conclusions}

There was no difference in postoperative morbidity and mortality in patients with AF versus those in SR. In patients with preoperative AF who underwent valve replacement with tissue prostheses MAZE offers significant survival advantage.

Published: 11 September 2013

doi:10.1186/1749-8090-8-S1-064

Cite this article as: Urban et al:: Impact of preoperative atrial fibrillation on mortality and cardiovascular outcomes in patients undergoing double valve surgery. Journal of Cardiothoracic Surgery 2013 8(Suppl 1): O64.

Submit your next manuscript to BioMed Central and take full advantage of:

- Convenient online submission

- Thorough peer review

- No space constraints or color figure charges

- Immediate publication on acceptance

- Inclusion in PubMed, CAS, Scopus and Google Scholar

- Research which is freely available for redistribution

\section{Biomed Central}

